\title{
PENERAPAN METODE GOAL PROGRAMMING UNTUK MEMAKSIMALKAN PERSEDIAAN DAN MEMINIMUMKAN BIAYA PENDISTRIBUSIAN BERAS DI PERUM BULOG DIVRE PALU
}

\author{
Hartini' ${ }^{1}$ A. Sahari² dan R. Ratianingsih ${ }^{3}$ \\ 1,2,3 Program Studi Matematika Jurusan Matematika FMIPA Universitas Tadulako \\ Jalan Soekarno-Hatta Km. 09 Tondo, Palu 94118, Indonesia. \\ 1hganiung@yahoo.com, 2agus sh@yahoo.com, 3ratianingsih@yahoo.com
}

\begin{abstract}
Perum Bulog, as an institution in charge of food in Indonesian's rice trade system, should have a sufficient supply of rice to adequate the community needness. In addition to optimizing the supply inventory, Perum Bulog also have to maximize the use of the truck transport in the distribution of rice and minimize the distribution costs. To optimize the overall performance, particularly in Perum Bulog Division Palu, we need a method that can resolve the problem with multipurpose, namely Goal Programming method. Goal Programming model formulation consists of 5 priorities and 5 constraint functions. These priorities are according to the capacity of warehouse safety stock levels (raskin and CBP), the target number of trucks for the raskin distribution in Palu, Donggala, Sigi, and distribution cost targets to be achieved. While the constraints consist of the warehouse capacity of Perum Bulog Division Palu, the number of trucks for the distribution of raskin in Palu, Donggala, Sigi, and distribution cost. The research results shows that the supply of rice based on the warehouse capacity fits to the needs of raskin and CBP distribution for 6 months with the number of inventories is $6.775 .920 \mathrm{~kg}$. The optimal distribution of raskin Palu, Donggala and Sigi require respectively 14 units trucks with each truk has a capacity of 15 ton, 24 units trucks with each truk has a capacity of 10 tons and 19 unit trucks with each truk has a capacity of 15 tons. This model can save the cost distribution by Rp. 6.455 .400 or $4,95 \%$ of the costs distribution incurred by Perum Bulog Division Palu.
\end{abstract}

Keywords $\quad$ : Cost Distribution, Goal Programming, Supplying, Trucks

\begin{abstract}
Abstrak
Perum Bulog sebagai suatu lembaga pangan di Indonesia yang mengurusi tata niaga beras harus mempunyai persediaan beras yang cukup untuk memenuhi kebutuhan masyarakat. Selain memaksimalkan persediaan, Perum Bulog juga harus memaksimalkan penggunaan angkutan untuk pendistribusian beras serta meminimumkan biaya pendistribusiannya. Untuk mengoptimalkan seluruh kinerja tersebut, khususnya pada Perum Bulog Divre Palu, dibutuhkan suatu metode yang dapat menyelesaikan persoalan dengan tujuan lebih dari satu yaitu metode Goal Programming. Formulasi model Goal Programming terdiri dari 5 prioritas dan 5 fungsi kendala. Prioritas-prioritas tersebut adalah kapasitas gudang sesuai dengan tingkat persediaan aman raskin dan
\end{abstract}


CBP (Cadangan Beras Pemerintah), target jumlah truk yang digunakan untuk distribusi raskin di Kota Palu, Kabupaten Donggala, Kabupaten Sigi, dan target biaya distribusi yang ingin dicapai. Sedangkan kendala terdiri atas persediaan beras di gudang Perum Bulog Divre Palu, banyaknya truk untuk pendistribusian raskin di Kota Palu, Kabupaten Donggala, Kabupaten Sigi, dan biaya distribusi. Dari hasil penelitian didapatkan persediaan beras berdasarkan kapasitas gudang dapat memenuhi kebutuhan penyaluran raskin maupun CBP selama 6 bulan dengan jumlah persediaan $6.775 .920 \mathrm{~kg}$. Untuk pendistribusian raskin yang optimal, Kota Palu membutuhkan 14 unit truk berkapasitas 15 ton, Kabupaten Donggala 24 unit truk berkapasitas 10 ton dan Kabupaten Sigi 19 unit truk berkapasitas 15 ton. Model ini dapat menghemat biaya pendistribusian sebesar Rp. 6.455.400 atau 4,95\% dari biaya distribusi yang selama ini dikeluarkan oleh Perum Bulog Divre Palu.

\section{Kata Kunci : Biaya Distribusi, Goal Programming, Persediaan, Truk}

\section{PENDAHULUAN}

\subsection{Latar Belakang}

Pangan merupakan kebutuhan dasar utama bagi manusia yang harus dipenuhi setiap saat. Hal tersebut yang mendasari terbitnya UU No. 7/1996 tentang Pangan. Menurut Firdaus, pangan di Indonesia identik dengan beras karena beras merupakan makanan pokok utama. Gangguan pada ketahanan pangan (beras) seperti kekurangan ketersediaan beras dan kenaikan harga beras dapat memicu kerawanan sosial, ketidakstabilan ekonomi dan politik serta secara menyeluruh dapat mengganggu stabilitas nasional. (Cory Trisilawaty, 2011) [3].

Berdasarkan Instruksi Presiden Nomor 8 Tahun 2008 tentang kebijakan perberasan menginstruksikan menteri dan kepala lembaga pemerintah non departemen tertentu, serta Gubernur dan Bupati/Walikota seluruh Indonesia untuk melakukan upaya peningkatan pendapatan petani, ketahanan pangan, pengembangan ekonomi pedesaan dan stabilitas ekonomi nasional. Dan secara khusus kepada Perum Bulog diinstruksikan untuk menyediakan Cadangan Beras Pemerintah (CBP) dan menyalurkan beras bersubsidi bagi kelompok masyarakat miskin dan rawan pangan.

Untuk memaksimalkan kinerja Perum Bulog, banyak yang harus dipenuhi antara lain meminimumkan biaya, memaksimalkan persediaan agar tidak terjadi kekurangan stok, serta jumlah truk yang digunakan untuk mengoptimalkan kegiatan penyaluran beras kepada masyarakat. Untuk mencapai tujuan yang beragam, dibutuhkan suatu metode analisis yang mengoptimalkan tujuan-tujuan tersebut, metode tersebut adalah metode Goal Programming.

Perum Bulog Divre Palu sebagai BUMN yang bergerak dalam penyediaan beras dijadikan studi kasus dalam penelitian ini, sehingga permasalahan memaksimalkan 
persediaan beras, mengoptimalkan jumlah truk dan meminimumkan biaya untuk pendistribusian beras kepada masyarakat menjadi fokus penelitian.

\subsection{Rumusan Masalah}

Berdasarkan uraian di atas, maka permasalahan pada penelitian ini adalah memaksimalkan persediaan beras untuk Raskin dan CBP tiap bulannya sesuai dengan jumlah pagu (kuota yang tersedia) dan kapasitas gudang, meminimumkan biaya pendistribusian raskin per bulan serta jumlah truk yang digunakan agar kegiatan penyaluran raskin ke 3 wilayah kerja Perum Bulog Divre Palu yaitu Kota Palu, Kabupaten Donggala dan Kabupaten Sigi dapat optimal dengan menggunakan metode Goal Programming.

\subsection{Tujuan Penelitian}

Tujuan dari penelitian ini adalah untuk memaksimalkan persediaan beras untuk Raskin dan CBP per bulan sesuai dengan pagu beras dan kapasitas gudang, meminimumkan biaya pendistribusian raskin per bulan serta jumlah truk yang digunakan agar kegiatan penyaluran raskin ke wilayah kerja Perum Bulog Divre Palu yaitu Kota Palu, Kabupaten Donggala, dan Kabupaten Sigi dapat optimal melalui metode Goal Programming.

\subsection{Batasan Masalah}

Adapun batasan masalah dalam penelitian ini yaitu:

1. Wilayah kerja Perum Bulog Divre Palu yang diteliti adalah Kota Palu, Kabupaten Donggala dan Kabupaten Sigi.

2. Persediaan beras yang diteliti terdiri dari Raskin dan CBP. Sedangkan untuk pengoptimalan jumlah truk dan biaya distribusi yang diteliti adalah Raskin.

\section{METODE PENELITIAN}

\subsection{Jenis dan Sumber Data}

Data yang digunakan dalam penelitian ini adalah data kualitatif yang merupakan data sekunder dari Perum Bulog Divre Palu dan agen penyewaan truk yaitu berupa data:

1. Kapasitas gudang beras Perum Bulog Divre Palu

2. Pagu beras per bulan untuk raskin dan CBP

3. Biaya pendistribusian raskin yang dikeluarkan Perum Bulog Divre Palu

4. Harga sewa truk pengangkut beras 


\subsection{Teknik Analisa Data}

Adapun teknik analisa data dari penelitian ini adalah data diperoleh dari Perum Bulog Divre Palu dan agen penyewaan truk, kemudian dilakukan pengolahan dengan membangun model matematika dari data tersebut dan menyelesaikan model menggunakan metode Goal Programming dengan tahapan penyelesaian yaitu menentukan variabel keputusan dan memformulasikan fungsi kendala dan fungsi tujuan dan kemudian dianalisa untuk menghasilkan persediaan beras, jumlah truk dan biaya pendistribusian yang optimal.

\subsubsection{Gambaran Umum Goal Programming}

Goal Programming pertama kali diperkenalkan oleh Charnes dan Cooper (Muhammad Arif, 2012)[1]. Program ini merupakan modifikasi atau variasi khusus program linier. Analisis Goal Programming bertujuan untuk meminimumkan jarak antara atau deviasi terhadap tujuan, target atau sasaran yang telah ditetapkan dengan usaha yang dapat ditempuh.

Menurut Elikson D. (2013)[2], Goal Programming adalah bentuk khusus atau modifikasi dari linear programming. Goal Programming ditujukan untuk mengatasi masalah dengan lebih dari satu tujuan. Tujuan-tujuan tersebut bisa saling berkaitan dan bisa juga saling bertentangan. Ketika tujuan yang satu berkaitan dengan tujuan lain, maka solusi terhadap satu tujuan menguntungkan tujuan yang lain.

Analisa Goal Programming bertujuan untuk meminimumkan penyimpanganpenyimpangan atau deviasi terhadap tujuan, target, atau sasaran yang telah ditetapkan, dengan usaha yang dapat ditempuh untuk mencapai target atau tujuan tersebut sesuai dengan syarat ikatan yang ada, yang membatasinya berupa sumber daya yang tersedia, teknologi yang ada, kendala tujuan, dan sebagainya.

\subsubsection{Model Goal Programming}

Model umum dari Goal Programming adalah:

Minimumkan:

$Z=\sum_{i=1}^{m} P_{i}\left(d_{i}{ }^{+}+{d_{i}}^{-}\right)$

Syarat ikatan:

$\checkmark \quad$ Kendala tujuan

$\sum_{i=1}^{m} a_{i j} X_{j}+d_{i}{ }^{-}-d_{i}{ }^{+}=b_{i}$

Untuk $i=1,2, \ldots, m$

$\checkmark \quad$ Kendala fungsional

$\sum_{i=1}^{m} g_{k j} X_{j} \leq$ atau $\geq C_{k}$ 
Untuk $k=1,2, \ldots, p$

Untuk $j=1,2, \ldots, n$

\section{Kendala non negatif}

$X_{j}, d_{i}{ }^{-}, d_{i}^{+} \geq 0$

dengan:

$P_{i}=$ prioritas ke $i$

$X_{j} \quad=$ variabel keputusan

$b_{i} \quad=$ target atau tujuan

$a_{i j}=$ koefisien fungsi kendala tujuan

$d_{i}{ }^{-}=$variabel deviasi yang mempresentasikan tingkat pencapaian dibawah target terhadap tujuan

$d_{i}{ }^{+}=$variabel deviasi yang mempresentasikan tingkat pencapaian diatas target terhadap tujuan

$g_{k j}=$ koefisien fungsi kendala biasa

$C_{k}=$ jumlah sumber daya $k$ yang tersedia

\subsubsection{Pembentukan Model Goal Programming}

Adapun langkah-langkah yang harus dilakukan dalam pembentukan model Goal Programming yaitu:

1. Menentukan variabel keputusan yang merupakan dasar dalam pembuatan model keputusan untuk mendapatkan solusi yang dicari.

2. Menentukan fungsi tujuan.

3. Merumuskan fungsi sasaran yaitu pada setiap tujuan ditambahkan variabel simpangan, baik simpangan positif $\left(d_{i}^{+}\right)$maupun simpangan negatif $\left(d_{i}{ }^{-}\right)$.

4. Menentukan prioritas utama.

5. Menentukan fungsi pencapaian dengan memilih variabel simpangan yang benar untuk dimasukkan dalam fungsi pencapaian.

6. Menyelesaikan model Goal Programming.

2.2.4. Penyelesaian Model Goal Programming Menggunakan Aplikasi QM For Windows

Program QM For Windows merupakan paket program komputer untuk penyelesaian persoalan-persoalan metode kuantitatif, manajemen sains atau riset operasi. Software ini dirancang oleh Howard J. Weiss tahun 1996 untuk membantu menyusun prakiraan anggaran untuk produksi bahan baku menjadi produk jadi atau 
setengah jadi pada produk pabrikasi. Langkah-langkah untuk menyelesaikan persoalan menggunakan aplikasi QM For Windows:

1. Jalankan aplikasi QM For Windows.

2. Pilih Goal Programming pada menu Module, kemudian pilih menu File-New.

3. Buat judul penyelesaian soal dengan mengisi bagian title. Misalnya "Goal Programming".

4. Isi set Number of Goal or Constraints dengan jumlah kendala dan set Number of Variables dengan jumlah variabel. Kemudian klik Ok.

5. Selanjutnya akan muncul tabel. Isikan angka-angka yang sesuai pada kotakkotak yang bersesuaian.

6. Setelah itu, klik Solve pada toolbar atau dengan menekan tombol F9 pada keyboard.

7. Jika terdapat data yang ingin diperbaiki, klik tombol Edit pada toolbar.

8. Simpan file dengan memilih menu File-Save.

\section{HASIL DAN PEMBAHASAN}

\subsection{Pengumpulan Data}

Data-data yang diperoleh:

1. Kapasitas gudang beras Perum Bulog Divre Palu

Persediaan beras raskin maupun CBP untuk wilayah Kota Palu, Kabupaten Sigi dan Kabupaten Donggala, Perum Bulog menempatkannya pada satu gudang yaitu Gudang Tondo dengan kapasitas gudang sebesar $7.000 .000 \mathrm{~kg}$.

2. Pagu beras per bulan untuk raskin dan $\mathrm{CBP}$

Tabel 1 : Pagu Raskin dan CBP Tahun 2013

\begin{tabular}{|l|c|c|}
\hline Nama Daerah & Pagu Raskin/Bulan (Kg) & Pagu CBP/Bulan (Kg) \\
\hline Palu & 205.095 & 100.000 \\
\hline Donggala & 350.085 & 100.000 \\
\hline Sigi Total & 274.140 & 100.000 \\
\hline \multicolumn{2}{|c|}{$:$ Perum Bulog Divre Palu } & 300.000 \\
\hline
\end{tabular}

3. Biaya pendistribusian raskin yang dikeluarkan Perum Bulog Divre Palu

Dalam melakukan pendistribusian beras dari gudang ke masing-masing daerah, Perum Bulog Divre Palu menggunakan truk bermuatan 5 ton, 10 ton atau 15 ton dengan hitungan biaya antara lain:
a. Transportasi : Rp. $145 / \mathrm{Kg}$
b. Upah buruh : Rp. $12.500 / \mathrm{Ton}$ atau Rp. $12.5 / \mathrm{Kg}$ 
Tabel 2 : Biaya Pendistribusian Raskin

\begin{tabular}{|c|c|}
\hline Nama Daerah & Biaya Pendistribusian Raskin (Rp) \\
\hline Palu & $32.302 .462,5$ \\
\hline Donggala & $55.138 .387,5$ \\
\hline Sigi & 43.177 .050 \\
\hline Total & 130.617 .900 \\
\hline
\end{tabular}

Sumber: Perum Bulog Divre Palu

4. Harga sewa truk pengangkut beras

Tabel 3 : Harga Sewa Truk Kapasitas 5 Ton, 10 Ton dan 15 Ton

\begin{tabular}{|c|c|c|c|}
\hline Nama Daerah & $\begin{array}{c}\text { Harga Sewa Truk } \\
\text { Kapasitas 5 Ton }(\mathrm{Rp})\end{array}$ & $\begin{array}{c}\text { Harga Sewa Truk } \\
\text { Kapasitas 10 Ton (Rp) }\end{array}$ & $\begin{array}{c}\text { Harga Sewa Truk } \\
\text { Kapasitas 15 Ton (Rp) }\end{array}$ \\
\hline Palu & 212.500 & 425.000 & 587.500 \\
\hline Donggala & 1.062 .500 & 2.125 .000 & 3.187 .500 \\
\hline Sigi & 762.500 & 1.575 .000 & 2.187 .500 \\
\hline
\end{tabular}

Sumber: Agen Penyewaan Truk "Khatulistiwa"

\subsection{Penentuan Variabel Keputusan $\left(\boldsymbol{X}_{\boldsymbol{j}}\right)$}

Variabel keputusan dinyatakan dengan:

$X_{1}=$ Persediaan beras di gudang

$X_{2}=$ Banyaknya truk pengangkut raskin untuk Kota Palu per bulan

$X_{3}=$ Banyaknya truk pengangkut raskin untuk Kabupaten Donggala per bulan

$X_{4}=$ Banyaknya truk pengangkut raskin untuk Kabupaten Sigi per bulan

\subsection{Fungsi Tujuan dan Fungsi Kendala}

Minimumkan :

$Z=P_{1}\left(d_{1}{ }^{+}+{d_{1}}^{-}\right)+P_{2}\left(d_{2}{ }^{+}+{d_{2}}^{-}\right)+P_{3}\left(d_{3}{ }^{+}+{d_{3}}^{-}\right)+P_{4}\left(d_{4}{ }^{+}+{d_{4}}^{-}\right)+P_{5}\left(d_{5}{ }^{+}+d_{5}{ }^{-}\right)$

Kendala tujuan:

1. Kendala tujuan 1 (truk berkapasitas muatan 5 ton):

1.129.320 $X_{1}+d_{1}{ }^{-}-d_{1}{ }^{+}=7.000 .000 \mathrm{~kg}$

$5.000 X_{2}+d_{2}{ }^{-}-d_{2}{ }^{+}=205.095 \mathrm{~kg}$

$5.000 X_{3}+d_{3}{ }^{-}-d_{3}{ }^{+}=350.085 \mathrm{~kg}$

$5.000 X_{4}+d_{4}{ }^{-}-d_{4}{ }^{+}=274.140 \mathrm{~kg}$

$R p .212 .500 X_{5}+R p .1 .062 .500 X_{6}+R p .762 .500 X_{7}+d_{5}{ }^{-}-d_{5}{ }^{+}=R p .130 .617 .900$

2. Kendala tujuan 2 (truk berkapasitas muatan 10 ton):

1.129.320 $X_{1}+d_{1}{ }^{-}-d_{1}{ }^{+}=7.000 .000 \mathrm{~kg}$

$10.000 X_{2}+d_{2}{ }^{-}-d_{2}{ }^{+}=205.095 \mathrm{~kg}$

$10.000 X_{3}+d_{3}{ }^{-}-d_{3}{ }^{+}=350.085 \mathrm{~kg}$

$10.000 X_{4}+d_{4}{ }^{-}-d_{4}{ }^{+}=274.140 \mathrm{~kg}$

$R p .425 .000 X_{5}+R p .2 .125 .000 X_{6}+R p .1 .575 .000 X_{7}+d_{5}{ }^{-}-d_{5}{ }^{+}=R p .130 .617 .900$

3. Kendala tujuan 3 (truk berkapasitas muatan 15 ton):

$1.129 .320 X_{1}+d_{1}{ }^{-}-d_{1}{ }^{+}=7.000 .000 \mathrm{~kg}$

$15.000 X_{2}+d_{2}{ }^{-}-d_{2}{ }^{+}=205.095 \mathrm{~kg}$ 
$15.000 X_{3}+d_{3}{ }^{-}-d_{3}{ }^{+}=350.085 \mathrm{~kg}$

$15.000 X_{4}+d_{4}{ }^{-}-d_{4}{ }^{+}=274.140 \mathrm{~kg}$

$R p \cdot 587.500 X_{5}+R p \cdot 3.187 .500 X_{6}+R p \cdot 2 \cdot 187.500 X_{7}+d_{5}{ }^{-}-d_{5}{ }^{+}=R p \cdot 130.617 .900$

Kendala non negatif:

$X_{1}, X_{2}, X_{3}, X_{4}, d_{1}{ }^{-}, d_{2}{ }^{-}, d_{3}{ }^{-}, d_{4}{ }^{-}, d_{5}{ }^{-}, d_{1}{ }^{+}, d_{2}{ }^{+}, d_{3}{ }^{+}, d_{4}{ }^{+}, d_{5}{ }^{+} \geq 0$

dengan:

$\mathrm{X}_{1}=$ Banyaknya persediaan beras di gudang Perum Bulog Divre Palu

$\mathrm{X}_{2} \quad=$ Banyaknya truk pengangkut raskin untuk Kota Palu per bulan

$\mathrm{X}_{3}=$ Banyaknya truk pengangkut raskin untuk Kabupaten Donggala per bulan

$\mathrm{X}_{4} \quad=$ Banyaknya truk pengangkut raskin untuk Kabupaten Sigi per bulan

$\mathrm{X}_{5} \quad=$ Jumlah truk terhadap banyaknya raskin yang didistribusikan di Kota Palu

$\mathrm{X}_{6}=$ Jumlah truk terhadap banyaknya raskin yang didistribusikan di Kabupaten Donggala

$\mathrm{X}_{7}=$ Jumlah truk terhadap banyaknya raskin yang didistribusikan di Kabupaten Sigi

$\mathrm{a}_{11} \quad=$ Pagu raskin dan pagu CBP perbulan

$a_{12}, a_{13}, a_{14}=$ Kapasitas muatan truk 5 ton

$a_{22}, a_{23}, a_{24}=$ Kapasitas muatan truk 10 ton

$a_{32}, a_{33}, a_{34}=$ Kapasitas muatan truk 15 ton

$\mathrm{d}_{1}{ }^{-} \quad=$ Persediaan beras yang ditetapkan diatas target

$\mathrm{d}_{1}{ }^{+} \quad=$ Persediaan beras yang ditetapkan dibawah target

$\mathrm{d}_{2}{ }^{-} \quad=$ Jumlah truk untuk distribusi raskin Kota Palu yang ditetapkan diatas target

$\mathrm{d}_{2}{ }^{+} \quad=$ Jumlah truk untuk distribusi raskin Kota Palu yang ditetapkan dibawah target

$\mathrm{d}_{3}{ }^{-} \quad=$ Jumlah truk untuk distribusi raskin Kabupaten Donggala yang ditetapkan diatas target

$\mathrm{d}_{3}{ }^{+} \quad=$ Jumlah truk untuk distribusi raskin Kabupaten Donggala yang ditetapkan dibawah target

$\mathrm{d}_{4}{ }^{-} \quad=$ Jumlah truk untuk distribusi raskin Kabupaten Sigi yang ditetapkan diatas target

$\mathrm{d}_{4}{ }^{+} \quad=$ Jumlah truk untuk distribusi raskin Kabupaten Sigi yang ditetapkan dibawah target

$\mathrm{d}_{5}{ }^{-} \quad=$ Jumlah rupiah dimana target biaya distribusi kurang dari biaya distribusi yang ditetapkan Perum Bulog Divre Palu

$\mathrm{d}_{5}{ }^{+} \quad=$ Jumlah rupiah dimana target biaya distribusi melebihi biaya distribusi yang ditetapkan Perum Bulog Divre Palu 


\subsection{Penyelesaian Goal Programming Menggunakan Aplikasi QM For Windows}

1. Kendala tujuan 1 (Truk berkapasitas muatan 5 ton)

Tabel 4 : Tampilan kendala tujuan 1 yang diisi pada kotak-kotak yang bersesuaian

\begin{tabular}{|l|c|c|c|c|c|c|c|c|c|c|}
\hline & Wt(d+) & Prty(d+) & Wt(d-) & Prty(d-) & X1 & X2 & X3 & X4 & RHS \\
\hline Goal/Cnstrnt 1 & 1 & 1 & 1 & 1 & 1129320 & 0 & 0 & 0 & $=$ & 7000000 \\
\hline Goal/Cnstrnt 2 & 1 & 2 & 1 & 2 & 0 & 5000 & 0 & 0 & $=$ & 205095 \\
\hline Goal/Cnstrnt 3 & 1 & 3 & 1 & 3 & 0 & 0 & 5000 & 0 & $=$ & 350085 \\
\hline Goal/Cnstrnt 4 & 1 & 4 & 1 & 4 & 0 & 0 & 0 & 5000 & $=$ & 274140 \\
\hline Goal/Cnstrnt 5 & 1 & 5 & 1 & 5 & 0 & 212500 & 1062500 & 762500 & $=$ & 130617900 \\
\hline
\end{tabular}

Tabel 5 : Hasil kendala tujuan 1

\begin{tabular}{|c|c|c|c|c|c|c|c|c|c|c|c|c|c|c|c|}
\hline & $\mathrm{X} 1$ & $\mathrm{X} 2$ & $\mathrm{X} 3$ & $\mathrm{X} 4$ & $d-1$ & $d-2$ & $d-3$ & $d-4$ & $d-5$ & $d+1$ & $d+2$ & $d+3$ & $d+4$ & $d+5$ & RHS \\
\hline Goal/Cnstrnt 1 & 1 & 0 & 0 & 0 & 0 & 0 & 0 & 0 & 0 & 0 & 0 & 0 & 0 & 0 & 6,2 \\
\hline Goal/Cnstrnt 2 & 0 & 1 & 0 & 0 & 0 & 0 & 0 & 0 & 0 & 0 & 0 & 0 & 0 & 0 & 41,02 \\
\hline Goal/Cnstrnt 3 & 0 & 0 & 1 & 0 & 0 & 0 & 0 & 0 & 0 & 0 & 0 & 0 & 0 & 0 & 70,02 \\
\hline Goal/Cnstrnt 4 & 0 & 0 & 0 & 1 & 0 & 0 & 0 & 0 & 0 & 0 & 0 & 0 & 0 & 0 & 54,83 \\
\hline Goal/Cnstrnt 5 & 0 & 0 & 0 & 0 & 0 & $-42,5$ & $-212,5$ & $-152,5$ & 1 & 0 & 42,5 & 212,5 & 152,5 & -1 & 5701954 \\
\hline Priority 5 & 0 & 0 & 0 & 0 & 0 & $-42,5$ & $-212,5$ & $-152,5$ & 0 & 0 & 42,5 & 212,5 & 152,5 & -2 & 5701954 \\
\hline Priority 4 & 0 & 0 & 0 & 0 & 0 & 0 & 0 & -1 & 0 & 0 & 0 & 0 & -1 & 0 & 0 \\
\hline Priority 3 & 0 & 0 & 0 & 0 & 0 & 0 & -1 & 0 & 0 & 0 & 0 & -1 & 0 & 0 & 0 \\
\hline Priority 2 & 0 & 0 & 0 & 0 & 0 & -1 & 0 & 0 & 0 & 0 & -1 & 0 & 0 & 0 & 0 \\
\hline Priority 1 & 0 & 0 & 0 & 0 & -1 & 0 & 0 & 0 & 0 & -1 & 0 & 0 & 0 & 0 & 0 \\
\hline
\end{tabular}


2. Kendala tujuan 2 (truk berkapasitas muatan 10 ton)

Tabel 6 : Tampilan kendala tujuan 2 yang diisi pada kotak-kotak yang bersesuaian

\begin{tabular}{|c|c|c|c|c|c|c|c|c|c|c|}
\hline & $\mathrm{Wt}(\mathrm{d}+)$ & Prty(d+) & $\mathrm{Wt}(\mathrm{d}-)$ & Prty(d-) & $\mathrm{X} 1$ & $\mathrm{X} 2$ & $\mathrm{X} 3$ & $\mathrm{X} 4$ & & RHS \\
\hline Goal/Cnstrnt 1 & 1 & 1 & 1 & 1 & 1129320 & 0 & 0 & 0 & $=$ & 7000000 \\
\hline Goal/Cnstrnt 2 & 1 & 2 & 1 & 2 & 0 & 1000 & 0 & 0 & $=$ & 205095 \\
\hline Goal/Cnstrnt 3 & 1 & 3 & 1 & 3 & 0 & 0 & 1000 & 0 & $=$ & 350085 \\
\hline Goal/Cnstrnt 4 & 1 & 4 & 1 & 4 & 0 & 0 & 0 & 1000 & $=$ & 274140 \\
\hline Goal/Cnstrnt 5 & 1 & 5 & 1 & 5 & 0 & 425000 & 2125000 & 1575000 & $=$ & 130617900 \\
\hline
\end{tabular}

Tabel 7 : Hasil kendala tujuan 2

\begin{tabular}{|c|c|c|c|c|c|c|c|c|c|c|c|c|c|c|c|}
\hline & $\mathrm{X} 1$ & $\mathrm{X} 2$ & $\mathrm{X} 3$ & $\mathrm{X} 4$ & $\mathrm{~d}-1$ & $\mathrm{~d}-2$ & $\mathrm{~d}-3$ & $\mathrm{~d}-4$ & $\mathrm{~d}-5$ & $\mathrm{~d}+1$ & $\mathrm{~d}+2$ & $\mathrm{~d}+3$ & $\mathrm{~d}+4$ & $\mathrm{~d}+5$ & $\mathrm{RHS}$ \\
\hline Goal/Cnstrnt 1 & 1 & 0 & 0 & 0 & 0 & 0 & 0 & 0 & 0 & 0 & 0 & 0 & 0 & 0 & 6,2 \\
\hline Goal/Cnstrnt 2 & 0 & 1 & 0 & 0 & 0 & 0 & 0 & 0 & 0 & 0 & 0 & 0 & 0 & 0 & 20,51 \\
\hline Goal/Cnstrnt 3 & 0 & 0 & 1 & 0 & 0 & 0 & 0 & 0 & 0 & 0 & 0 & 0 & 0 & 0 & 35,01 \\
\hline Goal/Cnstrnt 4 & 0 & 0 & 0 & 1 & 0 & 0 & 0 & 0 & 0 & 0 & 0 & 0 & 0 & 0 & 27,41 \\
\hline Goal/Cnstrnt 5 & 0 & 0 & 0 & 0 & 0 & $-42,5$ & $-212,5$ & $-157,5$ & 1 & 0 & 42,5 & 212,5 & 157,5 & -1 & 4331254 \\
\hline Priority 5 & 0 & 0 & 0 & 0 & 0 & $-42,5$ & $-212,5$ & $-157,5$ & 0 & 0 & 42,5 & 212,5 & 157,5 & -2 & 4331254 \\
\hline Priority 4 & 0 & 0 & 0 & 0 & 0 & 0 & 0 & -1 & 0 & 0 & 0 & 0 & -1 & 0 & 0 \\
\hline Priority 3 & 0 & 0 & 0 & 0 & 0 & 0 & -1 & 0 & 0 & 0 & 0 & -1 & 0 & 0 & 0 \\
\hline Priority 2 & 0 & 0 & 0 & 0 & 0 & -1 & 0 & 0 & 0 & 0 & -1 & 0 & 0 & 0 & 0 \\
\hline Priority 1 & 0 & 0 & 0 & 0 & -1 & 0 & 0 & 0 & 0 & -1 & 0 & 0 & 0 & 0 & 0 \\
\hline
\end{tabular}


3. Kendala tujuan 3 (Truk berkapasitas muatan 15 ton)

Tabel 8 : Tampilan kendala tujuan 3 yang diisi pada kotak-kotak yang bersesuaian

\begin{tabular}{|c|c|c|c|c|c|c|c|c|c|c|}
\hline & $W t(d+)$ & $\operatorname{Prty}(d+)$ & $\mathrm{Wt}(\mathrm{d}-)$ & Prty(d-) & $\mathrm{X} 1$ & $\mathrm{X} 2$ & X3 & $X 4$ & & RHS \\
\hline Goal/Cnstrnt 1 & 1 & 1 & 1 & 1 & 1129320 & 0 & 0 & 0 & $=$ & 7000000 \\
\hline Goal/Cnstrnt 2 & 1 & 2 & 1 & 2 & 0 & 1500 & 0 & 0 & $=$ & 205095 \\
\hline Goal/Cnstrnt 3 & 1 & 3 & 1 & 3 & 0 & 0 & 1500 & 0 & $=$ & 350085 \\
\hline Goal/Cnstrnt 4 & 1 & 4 & 1 & 4 & 0 & 0 & 0 & 1500 & $=$ & 274140 \\
\hline Goal/Cnstrnt 5 & 1 & 5 & 1 & 5 & 0 & 587500 & 3187500 & 2187500 & $=$ & 130617900 \\
\hline
\end{tabular}

Tabel 9 : Hasil kendala tujuan 2

\begin{tabular}{|c|c|c|c|c|c|c|c|c|c|c|c|c|c|c|c|}
\hline & $\mathrm{X} 1$ & $\mathrm{X} 2$ & $\mathrm{X} 3$ & $\mathrm{X} 4$ & $\mathrm{~d}-1$ & $\mathrm{~d}-2$ & $\mathrm{~d}-3$ & $\mathrm{~d}-4$ & $\mathrm{~d}-5$ & $\mathrm{~d}+1$ & $\mathrm{~d}+2$ & $\mathrm{~d}+3$ & $\mathrm{~d}+4$ & $\mathrm{~d}+5$ & $\mathrm{RHS}$ \\
\hline Goal/Cnstrnt 1 & 1 & 0 & 0 & 0 & 0 & 0 & 0 & 0 & 0 & 0 & 0 & 0 & 0 & 0 & 6,2 \\
\hline Goal/Cnstrnt 2 & 0 & 1 & 0 & 0 & 0 & 0 & 0 & 0 & 0 & 0 & 0 & 0 & 0 & 0 & 13,67 \\
\hline Goal/Cnstrnt 3 & 0 & 0 & 1 & 0 & 0 & 0 & 0 & 0 & 0 & 0 & 0 & 0 & 0 & 0 & 23,34 \\
\hline Goal/Cnstrnt 4 & 0 & 0 & 0 & 1 & 0 & 0 & 0 & 0 & 0 & 0 & 0 & 0 & 0 & 0 & 18,28 \\
\hline Goal/Cnstrnt 5 & 0 & 0 & 0 & 0 & 0 & $-39,17$ & $-212,5$ & $-145,83$ & 1 & 0 & 39,17 & 212,5 & 145,83 & -1 & 8213204 \\
\hline Priority 5 & 0 & 0 & 0 & 0 & 0 & $-39,17$ & $-212,5$ & $-145,83$ & 0 & 0 & 39,17 & 212,5 & 145,83 & -2 & 8213204 \\
\hline Priority 4 & 0 & 0 & 0 & 0 & 0 & 0 & 0 & -1 & 0 & 0 & 0 & 0 & -1 & 0 & 0 \\
\hline Priority 3 & 0 & 0 & 0 & 0 & 0 & 0 & -1 & 0 & 0 & 0 & 0 & -1 & 0 & 0 & 0 \\
\hline Priority 2 & 0 & 0 & 0 & 0 & 0 & -1 & 0 & 0 & 0 & 0 & -1 & 0 & 0 & 0 & 0 \\
\hline Priority 1 & 0 & 0 & 0 & 0 & -1 & 0 & 0 & 0 & 0 & -1 & 0 & 0 & 0 & 0 & 0 \\
\hline
\end{tabular}

Solusi-solusi diatas menghasilkan nilai non-integer, sehingga digunakan metode integer untuk menghasilkan nilai integer optimal dengan cara pembulatan nilai kebawah dan keatas. Nilai integer $X_{1}, X_{2}, X_{3}$, dan $X_{4}$ kemudian dimasukkan kedalam fungsi kendala sehingga diperoleh nilai $X_{1}, X_{2}, X_{3}$, dan $X_{4}$ optimal adalah sebagai berikut: 
Tabel 10 : Nilai $\mathrm{X}_{1}, \mathrm{X}_{2}, \mathrm{X}_{3}$, dan $\mathrm{X}_{4}$ optimal

\begin{tabular}{|l|c|c|c|}
\hline \multicolumn{1}{|c|}{ Kendala } & $\begin{array}{c}\text { Kendala tujuan } 1 \text { (truk } \\
\text { berkapasitas } 5 \text { ton) }\end{array}$ & $\begin{array}{c}\text { Kendala tujuan } 2 \text { (truk } \\
\text { berkapasitas } 10 \text { ton) }\end{array}$ & $\begin{array}{c}\text { Kendala tujuan } 3 \text { (truk } \\
\text { berkapasitas } 15 \text { ton) }\end{array}$ \\
\hline Persediaan beras $\left(\mathrm{X}_{1}\right)$ & 6 bulan & 6 bulan & 6 bulan \\
\hline Jumlah truk optimal Kota Palu $\left(\mathrm{X}_{2}\right)$ & 41 unit & 21 unit & 3 unit \\
\hline Jumlah truk optimal Kabupaten Donggala $\left(\mathrm{X}_{3}\right)$ & 70 unit & 28 unit & 24 unit \\
\hline Jumlah truk optimal Kabupaten Sigi $\left(\mathrm{X}_{4}\right)$ & 55 unit & $\square$ p.3.217.900 & 19 unit \\
\hline Biaya distribusi optimal & $\square$ p.5.592.900 & & \\
\hline
\end{tabular}

\subsection{Model Kombinasi Kendala Tujuan}

Model ini juga dapat dikombinasikan untuk memperoleh biaya yang lebih minimum lagi. Adapun kombinasi truk yang diperoleh yaitu:

Tabel 11 : Kombinasi kapasitas dan jumlah truk

\begin{tabular}{|c|c|c|c|c|c|c|}
\hline Kombinasi & $\begin{array}{l}\text { Kapasitas yang } \\
\text { digunakan untuk } \\
\text { Kota Palu }\end{array}$ & $\begin{array}{c}\text { Kapasitas yang } \\
\text { digunakan untuk } \\
\text { Kabupaten Donggala }\end{array}$ & $\begin{array}{l}\text { Kapasitas yang } \\
\text { digunakan untuk } \\
\text { Kabupaten Sigi }\end{array}$ & $\begin{array}{l}\text { Jumlah truk berturut- } \\
\text { turut (Palu, Donggala, } \\
\text { Sigi) }\end{array}$ & $\begin{array}{c}\text { Jumlah biaya } \\
\text { distribusi }\end{array}$ & $\begin{array}{l}\text { Penghematan } \\
\text { yang dihasilkan }\end{array}$ \\
\hline 1 & 5 Ton & 5 Ton & 5 Ton & $41,70,55$ & Rp. 125.025 .000 & Rp. 5.592.900 \\
\hline 2 & 5 Ton & 5 Ton & 10 Ton & $41,70,28$ & Rp. 127.187 .500 & Rp. 3.430 .400 \\
\hline 3 & 5 Ton & 5 Ton & 15 Ton & $41,70,19$ & Rp. 124.650 .000 & Rp. 5.967.900 \\
\hline 4 & 5 Ton & 10 Ton & 5 Ton & $41,35,55$ & Rp. 125.025 .000 & Rp. 5.592.900 \\
\hline 5 & 5 Ton & 10 Ton & 10 Ton & $41,35,28$ & Rp. 127.187 .500 & Rp. 3.430 .400 \\
\hline 6 & 5 Ton & 10 Ton & 15 Ton & $41,35,19$ & Rp. 124.650 .000 & Rp. 5.967.900 \\
\hline 7 & 5 Ton & 15 Ton & 5 Ton & $41,24,55$ & Rp. 127.150 .000 & Rp. 3.467 .900 \\
\hline 8 & 5 Ton & 15 Ton & 10 Ton & $41,24,28$ & Rp. 129.312 .500 & Rp. 1.305 .400 \\
\hline 9 & 5 Ton & 15 Ton & 15 Ton & $41,24,19$ & Rp. 126.775 .000 & Rp. 3.842 .900 \\
\hline 10 & 10 Ton & 5 Ton & 5 Ton & $21,70,55$ & Rp. 125.237 .500 & Rp. 5.380.400 \\
\hline 11 & 10 Ton & 5 Ton & 10 Ton & $21,70,28$ & Rp. 127.400 .000 & Rp. 3.217 .900 \\
\hline
\end{tabular}




\begin{tabular}{|c|c|c|c|c|c|c|}
\hline 12 & 10 Ton & 5 Ton & 15 Ton & $21,70,19$ & Rp. 124.862 .500 & Rp. 5.755 .400 \\
\hline 13 & 10 Ton & 10 Ton & 5 Ton & $21,35,55$ & Rp. 125.237 .500 & Rp. 5.380 .400 \\
\hline 14 & 10 Ton & 10 Ton & 10 Ton & $21,35,28$ & Rp. 127.400 .000 & Rp. 3.217 .900 \\
\hline 15 & 10 Ton & 10 Ton & 15 Ton & $21,35,19$ & Rp. 124.862 .500 & Rp. 5.755 .400 \\
\hline 16 & 10 Ton & 15 Ton & 5 Ton & $21,24,55$ & Rp. 127.362 .500 & Rp. 3.255 .400 \\
\hline 17 & 10 Ton & 15 Ton & 10 Ton & $21,24,28$ & Rp. 129.525 .000 & Rp. 1.092 .900 \\
\hline 18 & 10 Ton & 15 Ton & 15 Ton & $21,24,19$ & Rp. 126.987 .500 & Rp. 3.630 .400 \\
\hline 19 & 15 Ton & 5 Ton & 5 Ton & $14,70,55$ & Rp. 124.537 .500 & Rp. 6.080 .400 \\
\hline 20 & 15 Ton & 5 Ton & 10 Ton & $14,70,28$ & Rp. 126.700 .000 & Rp. 3.917 .900 \\
\hline 21 & 15 Ton & 5 Ton & 15 Ton & $14,70,19$ & Rp. 124.162 .500 & Rp. 6.455 .400 \\
\hline 22 & 15 Ton & 10 Ton & 5 Ton & $14,35,55$ & Rp. 124.537 .500 & Rp. 6.080 .400 \\
\hline 23 & 15 Ton & 10 Ton & 10 Ton & $14,35,28$ & Rp. 126.700 .000 & Rp. 3.917 .900 \\
\hline 24 & 15 Ton & 10 Ton & 15 Ton & $14,35,19$ & Rp. 124.162 .500 & Rp. 6.455 .400 \\
\hline 25 & 15 Ton & 15 Ton & 5 Ton & $14,24,55$ & Rp. 126.662 .500 & Rp. 3.955 .400 \\
\hline 26 & 15 Ton & 15 Ton & 10 Ton & $14,24,28$ & Rp. 128.825 .000 & Rp. 1.792 .900 \\
\hline 27 & 15 Ton & 15 Ton & 15 Ton & $14,24,19$ & Rp. 126.287 .500 & Rp. 4.330 .400 \\
\hline
\end{tabular}

Dari kombinasi diatas diperoleh 2 kombinasi yang mempunyai biaya distribusi paling optimal yaitu kombinasi ke-21 dan kombinasi ke24. Tetapi yang dianggap paling optimal adalah kombinasi ke-24 dimana biaya distribusi optimal yaitu sebesar Rp. 124.162.500 dimana biaya distribusi sebelumnya yaitu Rp. 130.617.900, maka biaya distribusi dapat dihemat sebesar Rp. 6.455.400 dengan menggunakan 14 unit truk untuk Kota Palu dengan kapasitas muatan 15 ton, 35 unit truk untuk Kabupaten Donggala dengan kapasitas muatan 10 ton dan 19 unit truk untuk Kabupaten Sigi dengan kapasitas 15 ton. Selain penghematan biaya distribusi, kombinasi ini juga lebih menguntungkan dalam segi waktu karena penggunaan truk yang tidak banyak. 


\section{KESIMPULAN}

Berdasarkan penelitian dan uraian-uraian pada bab-bab sebelumnya, maka dapat disimpulkan bahwa:

1. Maksimal persediaan beras berdasarkan kapasitas gudang dapat memenuhi 6 bulan penyaluran raskin maupun CBP di wilayah Kota Palu, Kabupaten Donggala dan Kabupaten Sigi yaitu sebesar $6.775 .920 \mathrm{~kg}$ dengan kapasitas gudang $7.000 .000 \mathrm{~kg}$.

2. Jumlah truk optimal untuk pendistribusian raskin di Kota Palu yaitu 14 unit truk berkapasitas muatan 15 ton dengan jumlah yang harus didistribusikan yaitu 205.095 kg, Kabupaten Donggala 35 unit truk berkapasitas muatan 10 ton dengan jumlah yang harus didistribusikan yaitu $350.085 \mathrm{~kg}$ dan Kabupaten Sigi 19 unit truk berkapasitas muatan 15 ton dengan jumlah yang harus didistribusikan yaitu $274.140 \mathrm{~kg}$.

3. Biaya distribusi optimal adalah Rp. 124.162 .500 dimana biaya distribusi sebelumnya Rp. 130.617.900 sehingga dapat menghemat sebesar Rp. 6.455 .400

\section{DAFTAR PUSTAKA}

[1]. Arif, M. 2012. Model Optimasi Persediaan Bahan Bakar Minyak (BBM) pada Pertamina UPMS VII Depot Donggala dengan Menggunakan Metode Goal Programming. Fakultas MIPA Universitas Tadulako. Palu.

[2]. Damanik, E. 2013. Penerapan metode goal programming untuk mengoptimalkan produksi teh (studi kasus PT. Perkebunan Nusantara IV-Pabrik Teh Bah Butong). Fakultas MIPA Universitas Sumatera Utara. Medan.

[3]. Trisilawaty, C. 2011. Analisis Optimasi Rantai Pasok Beras dan Penggunaan Gudang Di Perum Bulog Divre DKI Jakarta. Sekolah Pascasarjana. Institut Pertanian Bogor. 